\title{
ANALISIS PELAKSANAAN REFORMASI BIROKRASI TINGKAT MIKRO PADA SEKRETARIAT JENDERAL MAJELIS PERMUSYAWARATAN RAKYAT REPUBLIK INDONESIA
}

\author{
Habsul Nurhadi \\ Institut Ilmu Sosial dan Manajemen STIAMI \\ tophabsul@yahoo.com
}

\begin{abstract}
ABSTRAK. Penelitian ini terinspirasi dari kenyataan masih rendahnya kesiapan reformasi birokrasi pada Sekretariat Jenderal MPR-RI tahun 2013, maupun rendahnya hasil evaluasi pelaksanaan reformasi birokrasi tahun 2014, sehingga nyaris tidak mendapatkan tunjangan kinerja (remunerasi). Penelitian bertujuan untuk mengetahui seberapa jauh Sekretariat Jenderal MPR-RI telah melaksanakan reformasi birokrasi.

Penelitian ini menggunakan pendekatan kualitatif, dengan dimensi studi kasus, yang disajikan secara deskriptif, dengan antara lain menggunakan teori Reinventing Government (1992) maupun teori Banishing Bureaucracy (1997). Paradigma penelitiannya adalah naturalistik, dimana pengamatan dan pengumpulan datanya dilakukan sebagaimana adanya.

Berdasarkan pengolahan data menunjukkan bahwa secara umum pelaksanaan reformasi birokrasi pada Sekretariat Jenderal MPR-RI 2010-2014 masih belum sepenuhnya berjalan sesuai dengan pedoman pelaksanaan reformasi birokrasi yang sudah diterbitkan oleh Kementerian Pendayagunaan Aparatur Negara dan Reformasi Birokrasi.
\end{abstract}

Kata Kunci: Reformasi Birokrasi, MPR-RI, Sekretariat Jenderal MPR-RI.

Abstract. This research inspired from the fact the low readiness of bureaucratic reform in the Secretariat General of the MPR-RI in 2013, as well as lack of the evaluation of bureaucratic reform in 2014, making it nearly did not get the performance benefits (remuneration). The study aims to find out how far the Secretariat General of the MPR-RI has been carrying out bureaucratic reform. This study adopted qualitative approaches, to dimension case study, presented in a descriptive, with between other uses the theory of reinventing government (1992) and the theory of banishing bureaucracy (1997). This research is naturalistic paradigm, where observation and data collection done just as there are.

Based on data processing suggests that in generally the bureaucracy reform in the Secretariat General of the MPR-RI 2010-2014 still not fully way implementation guidelines for the bureaucratic reforms are already published by the Ministry of Administrative State Apparatus and Bureaucratic Reform.

Keywords: bureaucratic reform, MPR-RI, the Secretariat General of the MPR-RI.

\section{PENDAHULUAN}

Sejak tahun 2011 sampai dengan tahun 2012 Kementerian Pendayagunaan Aparatur Negara dan Reformasi Birokrasi telah menerima pengajuan sebanyak 38 usulan pelaksanaan reformasi birokrasi dari Kementerian/Lembaga, terdiri 16 Kementerian/Lembaga pada tahun 2011, dan 22 Kementerian/Lembaga pada tahun 2012. Hasil penilaiannya oleh Kementerian Pendayagunaan Aparatur Negara dan
Reformasi Birokrasi diajukan kepada Komite Pengarah Reformasi Birokrasi Nasional (KPRBN), untuk mendapatkan keputusan.

Ternyata performa hasil nilai evaluasi pelaksanaan reformasi birokrasi pada Sekretariat Jenderal MPR-RI termasuk relatif rendah. Sewaktu Sekretariat Jenderal MPR-RI mengajukan usulan pelaksanaan reformasi birokrasi yang pertamakalinya pada tahun 2012, maka berdasarkan hasil penilaian oleh Kementerian Pendayagunaan Aparatur 
Negara dan Reformasi Birokrasi tertanggal 21 Febuari 2013, kesiapan reformasi birokrasi Sekretariat Jenderal MPR-RI hanya memperoleh nilai 29, atau berada pada level 1, sehingga dinyatakan belum lolos passing grade dan belum layak mendapatkan tunjangan kinerja (remunerasi).

Sedangkan dalam pengajuan yang kedua kalinya pada tahun 2013, berdasarkan hasil evaluasi tanggal 14 Oktober 2014, pelaksanaan reformasi birokrasi Sekretariat Jenderal MPR-RI mendapatkan hasil 44,18 persen, atau nilai $C$, sehingga sudah memenuhi batas minimum lolos passing grade dan mendapatkan remunerasi sebesar 40 persen.

Penelitian tesis ini bermaksud melakukan analisis pelaksanaan reformasi birokrasi tingkat mikro, khususnya pada kasus pelaksanaan road map reformasi birokrasi Sekretariat Jenderal Majelis Permusyawaratan Rakyat Republik Indonesia tahun 2010-2014.

\section{Reformasi Birokrasi (Bureaucratic Reform)}

Pengertian "reformasi" secara harfiah berasal dari kata "reform" atau "reformation", yang artinya "membentuk kembali" sesuai dengan hakikinya. Namun secara fungsional pemahamannya adalah membentuk kembali ke arah perbaikan, kemajuan, pembaharuan, dan penyempurnaan. Dengan demikian pemahaman mengenai "reformasi birokrasi" adalah membangun kembali kondisi birokrasi ke arah perbaikan, penyempurnaan dan pembaharuan, sesuai dengan tujuan birokrasi pemerintah, yaitu pemberian pelayanan publik yang tertib, teratur, lancar, serta efisien dan efektif (Istianto, 2013: 201)

Dalam studi administrasi publik, perdebatan mengenai optimalisasi pelayanan publik oleh pemerintah sebenarnya telah berlangsung cukup lama. Sejak beberapa dekade lalu, polemik sudah terjadi di kalangan para pakar mengenai cara untuk mewujudkan pemerintahan yang bersih dan efisien, tanggap, dan akuntabel. Masingmasing pakar memaparkan teori dan atau membantah dan memperbaiki teori yang ada sebelumnya.
Teori yang mapan menjadi paradigma dan di-mitos-kan, kemudian muncul teori baru untuk mendemistifikasi teori yang mapan tersebut. Teori Reinventing Government yang tergolong pada The New Public Management, misalnya,merupakan demistifikasi atas The Old Public Management. Bahkan sekarang telah muncul demistifikasi atas The New Public Management tersebut dengan munculnya konsep The New Public Service (Arisman, tanpa keterangan tahun).

Menurut Arisman, dinamika konsep administrasi publik dari The Old Public Management, lalu menjadi The New Public Management, dan kemudian menjadi The New Public Service tersebut, beserta ulasan detail tentang konsep dan kritik atas konsepnya, dapat dilihat dalam buku karya Janet V. Denhardt dan Robert B. Denhardt, yang berjudul The New Public Service: Serving, not Steering (2007). Sedangkan khusus untuk gagasan-gagasan The old Public Administration dapat dilihat dalam buku karya Jay M. Shafritz dan Albert C. Hyde, yang berjudul Classics of Public Administration (1997).

Para ilmuwan politik, misalnya, telah memperdebatkan kemungkinan mengembangkan good government dan representative government, sejak awal abad 20an, sebagaimana yang telah diungkapkan oleh John Stuart Mill, dalam buku karyanya yang berjudul Utilitarianism, On Liberty, Consideration on Representative Government, Vermont: Everyman (1993).

Bahkan tidak hanya itu, Woodrow Wilson pada tahun 1887 dalam The Study of Administration telah mengemukakan konsep dikotomi politik dan administrasi untuk menciptakan pemerintahan yang efisien. Selain Wilson, ada Max Weber (1922) dengan teori The Ideal Type of Bureucracy, Luther Gullick (1937) dengan konsep POSDCORB, Frank J. Goodnow (1900) dengan konsepnya yang tertuang dalam makalahnya Politics and Administration, Frederick W. Taylor (1912) dengan konsepnya Scientific Management, Herbert A. Simon (1946) dengan konsepnya The Proverbs of Administration, dan masih 
Habsul, Analisis Pelaksanaan Reformasi Birokrasi Tingkat Mikro...

banyak lagi yang ikut memberikan kontribusi konsep dan teori dalam optimalisasi pelayanan publik.

Sedangkan gagasan Reinventing Government yang dicetuskan oleh David Osborne dan Ted Gaebler (1992) adalah gagasan mutakhir yang mengkritisi dan memperbaiki konsep-konsep dan teori-teori klasik tersebut untuk optimalisasi pelayanan publik. Gagasan David Osborne dan Ted Gaebler tersebut tertuang dalam karyanya yang berjudul Reinventing Government: How the Entrepreneurial Spirit is Transforming the Public Sector yang dipublikasikan pada tahun 1992 dan buku karya David Osborne dan Peter Plastrik yang berjudul Banishing Bureaucracy: The Five Strategies for Reinventing Government, yang dipublikasikan pada tahun 1997.

Gagasan yang dikemukakan oleh David Osborne dan Ted Gaebler pada tahun 1992 tersebut sangat mempengaruhi mulai munculnya gerakan reformasi di dunia. Awalnya, gagasan Osborne dan Gaebler tersebut berkaitan dengan solusi atas fenomena birokrasi pemerintahan di Amerika Serikat yang dianggap sangat gemuk dan memberatkan anggaran negara. Ternyata pemikiran Osborne dan Gaebler tersebut telah mengilhami gerakan reformasi birokrasi di berbagai negara di dunia (Hamdi dan Khairi, 2014: 76).

Ide utama dari reformasi Osborne dan Gaebler ini adalah mengurangi peran negara terhadap hal-hal yang seharusnya dapat dilakukan oleh swasta serta memaksimalkan peluang yang ada untuk memperoleh penerimaan selain pajak. Konsekuensi dari pemikiran tersebut melahirkan perampingan birokrasi (Osborne dan Plastrik, 2004, dalam Hamdi dan Khairi, 2014: 76).

Rangkaian pemikiran tersebut menginspirasi timbulnya reformasi birokrasi baik melalui privatisasi, seperti yang dicanangkan Inggris semasa kepemimpinan Perdana Menteri Margaret Thatcher, maupun melalui penerapan praktik birokrasi pemerintah bergaya bisnis seperti di Amerika Serikat. Secara umum, prinsip-prinsip pelayanan publik dalam New Public Management (NPM) di era Margaret Thatcher meliputi restrukturisasi organisasi, reformasi penganggaran, manajemen yang berorientasi pada penerima pelayanan, aparatur pemerintahan yang profesional, demokratisasi, dan pelibatan partisipasi masyarakat (Denhardt \& Denhardt, 2007, dalam Hamdi dan Khairi, 2014: 76).

Konsep pemerintahan entrepreneur Osborn dan Gaebler yang mencoba menemukan nilai-nilai baru (reinventing) di bidang pemerintahan ternyata mempunyai kekuatan dan sekaligus kelemahan. Kritik terhadap konsep pemerintahan entrepreneur adalah karena terlalu bias pada "new administrative values" yang lebih banyak menitik beratkan pada orientasi goal governance dengan meminggirkan nilai-nilai administrasi klasik yang sebenarnya masih potensial yang berbasis pada rule governance (Muskamal, 2014).

Gerald E. Caiden, seorang pakar reformasi administrasi dari University of Southern California, dalam buku karyanya yang berjudul Administrative Reform Comes of Age (1991), mengatakan bahwa reformasi sistem administrasi tidak pernah mencapai inti permasalahan, karena seringkali hanya sebatas formalitas semata. Reformasi yang dilakukan oleh pemerintah biasanya tidak cukup luas dan tidak mendalam. Bahkan, cukup banyak negara yang tidak memiliki perhatian terhadap reformasi birokrasi (Caiden, 1991, dalam Dwiyanto, 2015: 105).

Gerald E Caiden (dalam Nugroho, 2013) mengungkapkan, bahwa banyak negara berkembang yang hampir selalu gagal melakukan reformasi birokrasi karena tidak mempunyai faktor-faktor yang dimiliki negara maju, yang sukses melakukan reformasi birokrasi, yakni (1) sistem administrasi yang berjalan dengan baik dari generasi ke generasi, (2) masyarakat dan birokrasi sudah saling menyesuakan diri menjadi sebuah relasi produktif, (3) lembaga pemerintahan yang kuat, terutama karena warganegara menghormati lembaga pemerintahan, dan (4) mempunyai sumberdaya yang mencukupi untuk mendukung reformasi birokrasi, termasuk di dalamnya manusia, teknologi, dan anggaran (Nugroho, 2013: 2-3). 
Dari sudut tinjauan yang lain, Komarudin (2014: 1) mengemukakan bahwa reformasi birokrasi merupakan perubahan signifikan secara mindset dan culture set atas elemenelemen birokrasi, yaitu kelembagaan, sumberdaya manusia aparatur, ketatalaksanaan, akuntabilitas, pengawasan, dan pelayanan publik. Sementara Riant Nugroho merumuskan, bahwa secara umum reformasi birokrasi merupakan bagian dari strategi besar dalam ilmu perilaku organisasi yang lebih dikenal sebagai manajemen perubahan, dimana melaksanakan reformasi birokrasi sama dengan melakukan manajemen perubahan dalam birokrasi (Nugroho, 2013: $15)$.

Manajemen perubahan adalah sebuah pendekatan proaktif untuk memahami bagaimana seharusnya perubahan dilaksanakan dalam suatu organisasi. Menurut Bernis Walmsley, dalam bukunya Managing Change, manajemen perubahan memahami bahwa perubahan harus direncanakan, diorganisasikan, dipimpin, dan dikendalikan (Nugroho, 2013: 4).

Reformasi birokrasi memang dinyatakan dalam banyak istilah, yang pada dasarnya berkaitan dengan upaya membangun pemerintahan agar benar-benar memiliki kemampuan untuk memenuhi tujuannya, yakni mewujudkan kehidupan rakyat yang sejahtera, adil, dan bermartabat (Hamdi dan Khairi, 2014: 76).

Dengan berbagai istilah tersebut - antara lain reformasi administratif, reformasi administrasi publik, dan reformasi sektor publik - kebutuhan akan reformasi birokrasi secara umum bertujuan untuk mengatasi kelemahan yang dimiliki oleh birokrasi dalam penyelenggaraan pemerintahan, seperti birokrasi yang dipandang lamban, kaku, tidak efisien, berbelit-belit, korup, tidak responsif terhadap tuntutan masyarakat, serta berbagai patologi birokrasi lainnya.

Khusus untuk kondisi Indonesia, menurut Muskamal (2014), birokrasi Indonesia perlu melakukan reformasi secara menyeluruh. Reformasi itu sesungguhnya harus dilihat dalam kerangka teoritik dan empirik yang luas, mencakup didalamnya penguatan masyarakat sipil (civil society), supremasi hukum, strategi pembangunan ekonomi dan pembangunan politik yang saling terkait dan mempengaruhi. Dengan demikian, reformasi birokrasi juga merupakan bagian tak terpisahkan dalam upaya konsolidasi demokrasi. Namun, peralihan dari sistem otoritarian ke sistem demokratis dewasa ini merupakan periode yang amat sulit bagi proses reformasi birokrasi. Apalagi, kalau dikaitkan dengan kualitas birokrasi pemerintahan maupun realisasi otonomi daerah, serta maraknya penyalahgunaan wewenang pada birokrasi pemerintahan yang diperkirakan semakin sistemik dan bahkan merata ke daerah-daerah.

Globalisasi tak hanya menuntut peningkatan peran sektor swasta, tetapi juga menuntut sektor publik untuk memperbaiki kinerjanya dalam rangka melayani kebutuhan pasar global. Hal ini telah berlangsung di Thailand, Singapura, Malaysia, dan Filipina. Di Singapura, misalnya, munculnya pasar global ditanggapi pemerintah dengan meningkatkan kompetensi civil service agar mereka mampu menjawab tantangan zaman dan lebih kompetitif di dunia internasional. Birokrasi di Malaysia lebih diorientasikan ke bisnis untuk menggantikan peran aktif birokrasi dalam pembangunan dan meredefinisi perannya sebagai fasilitator dalam aktivitas sektor swasta. Dalam kasus di Thailand, munculnya peran birokrasi publik adalah untuk memfasilitasi kebijakan propasar seperti privatisasi dan berbagai aktivitas yang berkaitan dengan sektor swasta seperti business licensing, perdagangan internasional, dan pengawasan fiskal (Muskamal, 2014).

Perubahan birokrasi di Thailand belakangan ini juga lebih menempatkan dirinya sebagai katalisator untuk memfasilitasi aktivitas ekonomi yang civil service-nya berperan sebagai pendukung dan bukannya pemimpin. Hal yang sama juga dilakukan di Filipina. Hal ini dengan jelas menunjukkan bahwa perubahan birokrasi itu menekankan perlunya keterbukaan struktural untuk memungkinkan terjadinya pertukaran 
Habsul, Analisis Pelaksanaan Reformasi Birokrasi Tingkat Mikro...

gagasan dan perubahan inovasi. Meski demikian, tidak semua negara berhasil melakukan perubahan birokrasi. Singapura dan Malaysia tergolong cukup efektif mewujudkan beberapa reformasi administrasi, antara lain karena stabilitas politik dan kerja sama yang baik antara birokrasi dan pemimpin politik. Sementara itu, Indonesia, Thailand, dan Filipina kurang efektif dalam mewujudkan perubahan administrasi karena dominannya aparat birokrasi dan adanya konflik atau kolusi antara birokrasi dan elite politik.

Berkenaan dengan orientasi baru birokrasi yang lebih melihat ke pasar, kelak diharapkan keputusan didasarkan pada analisis Iogis dan melihat secara jeli implikasi dari kebijakan pro-pasar untuk legitimasi birokrasi publik, moralitas, dan motivasi pegawai negeri, serta mempertimbangkan manfaat dan kerugiannya bagi penduduk. Untuk itu, pembuat kebijakan perlu mempertimbangkan perbedaan mendasar antara sektor publik dan sektor swasta dalam hal tujuan, struktur, normanorma, meneliti secara kritis pelaksanaan ekonomi, sosial, dan keuntungan serta kerugian administrasi dalam transisi birokrasi, mengidentifikasi siapa saja yang diuntungkan dan siapa yang tidak diuntungkan dari perubahan birokrasi.

Pola birokrasi yang cenderung sentralisitik, dan kurang peka terhadap perkembangan ekonomi, sosial dan politik masyarakat harus ditinggalkan, dan diarahkan seiring dengan tuntutan masyarakat. Harus diciptakan birokrasi yang terbuka, profesional dan akuntabel, serta dapat memicu pemberdayaan masyarakat, dan mengutamakan pelayanan kepada masyarakat tanpa diskriminasi. Birokrasi demikian dapat terwujud apabila terbentuk suatu sistem dimana terjadi mekanisme birokrasi yang efisien dan efektif, dengan menjaga sinergi yang konstruktif diantara pemerintah, sektor swasta dan masyarakat (Muskamal, 2014).

Dengan makin besarnya peran yang dijalankan oleh masyarakat, maka seharusnya peran birokrasi lebih cenderung sebagai agen pembaharuan, pelayanan dan pemberdayaan masyarakat. Oleh karena itu, fungsi pengaturan dan pengendalian yang dilakukan oleh Negara adalah perumusan dan pelaksanaan kebijaksanaan yang berfungsi sebagai motivator dan fasilitator guna tercapainya swakarsa dan swadaya masyarakat termasuk dunia usaha. Peran lain yang seharusnya dijalankan oleh birokrasi adalah sebagai consensus building, yaitu membangun pemufakatan antara negara, sektor swasta dan masyarakat (Muskamal, 2014).

Peran ini harus dijalankan oleh birokrasi mengingat fungsinya sebagai agen pembaharuan dan faslitator. Sebagai agen perubahan, birokrasi harus mengambil inisiatif dan memelopori suatu kebijakan atau tindakan. Sedangkan sebagai fasilitator, birokrasi harus dapat memfasilitasi kepentingan-kepentingan yang muncul dari masyarakat, sektor swasta maupun kepentingan negara. Selain itu, pemisahan peran yang melekat pada aparatur pemerintah menjadi suatu keharusan.

Aparatur pemerintah adalah pelayan publik yang harus melayani masyarakat apapun latar belakangnya. Perbedaan ideologi maupun pilihan politik tidak boleh menghalangi birokrasi dalam mengemban perannya sebagai pelayan masyarakat. Dalam rangka optimalisasi peran birokrasi tersebut, maka kebijaksanaan debirokratisasi, deregulasi, dan desentralisasi perlu dilanjutkan dan dikawal pelaksanaannya, serta peningkatan pelayanan kepada masyarakat harus terus menerus ditingkatkan dan diusahakan (Muskamal, 2014). Oleh karenanya, menurut Muskamal, reformasi birokrasi menjadi suatu keharusan, mengingat implikasinya yang begitu luas bagi masyarakat dan negara. Perlu usaha-usaha serius agar pembaharuan birokrasi menjadi lancar dan berkelanjutan.

Reformasi birokrasi merupakan pekerjaan besar karena menyangkut sistem besar negara yang telah mengalami tradisi buruk selama kurun waktu yang cukup lama. Untuk dapat memutus tradisi lama dan menciptakan tatanan dan tradisi baru, perlu kepemimpinan yang kuat dan yang patut diteladani. Kepemimpinan yang kuat berarti hadirnya pemimpin-pemimpin yang berani dan tegas dalam membuat keputusan. Sedangkan keteladanan adalah keberanian dalam 
memberikan contoh kepada bawahan dan masyarakat.

Reformasi birokrasi diharapkan dapat berdampak langsung pada masyarakat, karena peran birokrasi yang utama adalah memberikan pelayanan kepada masyarakat. Pada tataran ini masyarakat dapat dilibatkan untuk mengawasi kinerja birokrasi. Patut rnenjadi perhatian semua pihak bahwa birokrasi merupakan kekuatan yang besar sekali, dimana kegiatannya menyentuh hampir setiap kehidupan warga negara. Maka kebijakan yang dibuat oleh birokrasi sangat mempengaruhi sendi-sendi kehidupan bermasyarakat dan bernegara, dikarenakan warga yang hidup dalam suatu negara terpaksa menerima kebijaksanaan yang telah dibuat oleh birokrasi. Selain itu, memang birokrasi merupakan garis terdepan yang berhubungan dengan pemberian pelayanan umum kepada masyarakat (Muskamal, 2014).

Dengan ungkapan yang lain, reformasi birokrasi yang seharusnya dilakukan oleh pemerintah Indonesia adalah reformasi yang dapat memberikan solusi secara menyeluruh dan terintegrasi terhadap semua persoalan yang dihadapi birokrasi Indonesia yang cenderung semakin kompleks, seperti praktik korupsi yang semakin meluas, struktur birokrasi yang rigid, kompleks, dan terfragmentasi, budaya kekuasaan yang berlebihan, politisasi birokrasi yang semakin meluas, kualitas aparatur yang buruk, serta kualitas pelayanan yang buruk. Sehingga kebijakan reformasi yang hanya mengandalkan pada perbaikan remunerasi, pembobotan jabatan, dan penataan organisasi, tentu tidak memadai untuk menjawab masalah birokrasi pemerintah di Indonesia, karena Indonesia membutuhkan kebijakan reformasi birokrasi yang visioner, holistik, dan koheren, dan bukannya kebijakan reformasi birokrasi yang tambal sulam, berdurasi pendek, dan tidak partisipatif (Dwiyanto, 2015: 105).

Menurut Agus Dwiyanto, apa yang termuat dalam Peraturan Presiden Nomor 81 Tahun 2010 tentang Grand Design Reformasi Birokrasi 2010-2025, perlu untuk ditinjau kembali secara menyeluruh. Visi, sasaran, area perubahan, dan strategi implementasi dari kebijakan reformasi birokrasi tersebut perlu didiskusikan secara terbuka dengan para pemangku kepentingan.

Selama ini kepemilikan publik terhadap kebijakan reformasi birokrasi sangat rendah, karena mereka tidak dilibatkan, dan kepentingan publik tidak menjadi arus utama dalam reformasi birokrasi, berhubung reformasi birokrasi tampaknya masih terbatas pada persoalan internal birokrasi, masih cenderung sebagai proyek pemerintah, dan belum menjadi gerakan sosial (Dwiyanto, 2015: 106).

\section{Metode (Methods)}

Penelitian ini menggunakan pendekatan kualitatif dengan dimensi studi kasus dan paradigma naturalistik, dengan antara lain menggunakan teori Reinventing Government dari Osborne dan Gaebler (1992) maupun teori Banishing Bureaucracy dari Osborne dan Plastrik (1997). Penelitian dilakukan pada bulan Agustus 2015, dengan melakukan wawancara mendalam, observasi, dan penggunaan data sekunder, untuk mengungkap kasus pelaksanaan road map reformasi birokrasi di Sekretariat Jenderal MPR-RI pada periode 2010-2014.

Informan dari penelitian analisis pelaksanaan reformasi birokrasi pada Sekretariat Jenderal MPR-RI ini meliputi (1) kelompok penentu kebijakan reformasi birokrasi, (2) kelompok pelaku reformasi birokrasi, dan (3) kelompok pemangku kepentingan (stakeholders) reformasi birokrasi. Dari kelompok penentu kebijakan reformasi birokrasi Sekretariat Jenderal MPRRI meliputi (1) Sekretaris Jenderal/Wakil Sekretaris Jenderal MPR-RI, dan (2) Kepala Biro Administrasi dan Pengawasan Setjen MPR-RI.

Dari kelompok pelaku reformasi birokrasi terdiri (1) Sekretaris Jenderal/Wakil Sekretaris Jenderal MPR-RI, (2) para Kepala Biro dan Kepala Pusat Pengkajian Setjen MPR-RI, (3) Kepala Bagian dan Kepala Sub Bagian pada Biro Sekretariat Jenderal MPRRI yang mengelola pelaksanaan reformasi 
Habsul, Analisis Pelaksanaan Reformasi Birokrasi Tingkat Mikro...

birokrasi, dan (4) Staf maupun pegawai biasa Sekretariat Jenderal MPR-RI.

Sedangkan dari kelompok pemangku kepentingan reformasi birokrasi terdiri Pimpinan (Ketua/Wakil Ketua) MPR-RI dan/atau Pimpinan Fraksi dan Kelompok Anggota MPR-RI, maupun Pimpinan Badan MPR-RI, yang kesemuanya dalam kapasitas jabatan sebagai pimpinan Alat Kelengkapan MPR-RI maupun dalam kapasitas sebagai Anggota biasa MPR-RI.

\section{Hasil dan Pembahasan (Results and Discussion)}

Pertama, Sekretariat Jenderal MPR-RI dalam pelaksanaan program Manajemen Perubahan sudah berhasil membentuk Tim Manajemen Perubahan sebagai bagian dari Tim Reformasi Birokrasi, namun masih belum berhasil menyusun Strategi Manajemen Perubahan dan Strategi Komunikasi. Selain itu, Sekretariat Jenderal MPR-RI juga masih belum berhasil membangun kesamaan persepsi, komitmen, konsistensi, serta keterlibatan dari seluruh tingkatan pegawai dalam pelaksanaan program dan kegiatan reformasi birokrasi.

Pada roadmap program manajemen perubahan pada reformasi birokrasi Sekretariat Jenderal MPR-RI terdapat penambahan butir-butir kegiatan yang tidak terdapat pada road map program manajemen perubahan reformasi birokrasi nasional, yakni (1) pembuatan Kode Etik Pegawai, (2) pelibatan pegawai dalam penyusunan rencana strategis, tata kelola dan pelaksanaan berbagai program dan kegiatan, serta (3) pembudayaan dialog, kerjasama tim dan keterbukaan komunikasi.

Adanya penambahan tiga butir program tersebut, diduga, pada awalnya dimaksudkan sebagai suatu kegiatan unggulan Sekretariat Jenderal MPR-RI dalam program manajemen perubahan reformasi birokrasi, guna meningkatkan kinerja pelaksanaan reformasi birokrasinya. Namun pada kenyataannya, dalam pelaksanaannya, ketiga butir kegiatan tersebut masih belum mampu menghasilkan kinerja yang optimal, misalnya saja Kode Etik Pegawai ternyata masih belum dapat selesai secara tuntas.
Kedua, Kedua, Sekretariat Jenderal MPR-RI dalam pelaksanaan program Penataan Peraturan Perundang-undangan masih belum berhasil melakukan identifikasi berbagai peraturan yang pernah diterbitkan di lingkungan Sekretariat Jenderal MPR-RI sebagai dasar untuk dilakukannya regulasi dan/atau deregulasi yang diperlukan.

Meskipun Meskipun kegiatan pada road map program penataan peraturan perundangundangan pada reformasi birokrasi Sekretariat Jenderal MPR-RI 2010-2014 telah tersusun lebih rinci, akan tetapi pada pelaksanaannya ternyata masih belum optimal kinerjanya, dikarenakan masih belum terkonsentrasinya pelaksana tugas penataan regulasi, belum adanya unit pelaksana tugas evaluasi dan penyempurna berbagai regulasi, serta masih belum selesainya pembuatan Panduan Pembuatan Peraturan.

Ketiga, Sekretariat Jenderal MPR-RI dalam pelaksanaan program Penataan dan Penguatan Organisasi selama periode tahun 2010-2014 sudah berhasil melakukan restrukturisasi organisasi Sekretariat Jenderal MPR-RI pada tahun 2013 dengan mengikuti susunan kelembagaan MPR-RI periode tahun 2009-2014, meskipun kemudian organisasi Sekretariat Jenderal MPR-RI terpaksa harus dilakukan penyesuaian lagi seiring dengan berubahnya susunan kelembagaan MPR-RI periode tahun 2014-2019, agar dapat lebih tepat fungsi dan lebih tepat ukuran (right sizing) sehingga dapat mendorong percepatan reformasi birokrasi.

Selain itu, Sekretariat Jenderal MPR-RI juga sudah melakukan upaya penguatan unit kerja yang menangani organisasi, tatalaksana, pelayanan publik, kepegawaian dan diklat, meskipun masih perlu terus disempurnakan lagi, agar mampu mendukung tercapainya tujuan dan sasaran reformasi birokrasi.

Sekretariat Jenderal MPR-RI memang telah berhasil menyusun dokumen Rencana Strategis Sekretariat Jenderal MPR-RI 20102014 pada akhir tahun 2009, bahkan sudah melakukan upaya revisi pada tahun 2011 dan tahun 2012. Sekretariat Jenderal MPR-RI juga telah berhasil menyusun dokumen Rencana Operasional setiap unit kerja pada bulan Desember 2013. Bahkan pada bulan Maret 
Jurnal Ilmiah Untuk Mewujudkan Masyarakat Madani ISSN 2355-309X

2014 juga sudah menyusun Rencana Strategis Teknokratik sebagai dasar evaluasi, serta menyusun Rencana Strategis 2015-2019.

Keempat, Sekretariat Jenderal MPR-RI dalam pelaksanaan program Penataan Tatalaksana telah berhasil menyusun Standar Operasional Prosedur (SOP) penyelenggaraan tugas dan fungsi, serta telah mulai berupaya membangun e-government, meskipun masih harus terus dikembangkan kemanfaatannya lebih lanjut, agar mampu mendukung tercapainya tujuan dan sasaran reformasi birokrasi.

Seyogyanya Sekretariat Jenderal MPR-RI juga mengikuti panduan pelaksanaan road map program penataan tatalaksana pada reformasi birokrasi nasional 2010-2014, dimana untuk mengukur pencapaian program penataan tatalaksana ini digunakan indikatorindikator keberhasilan yang mencakup (1) indikator proses standar operasional prosedur pelayanan publik, (2) indikator pengembangan e-government, dan indikator keterbukaan informasi publik.

Kelima, Sekretariat Jenderal MPR-RI dalam pelaksanaan program Penataan Sistem Manajemen Sumber Daya Manusia Aparatur selama periode tahun 2010-2014 telah berhasil melakukan penataan sistem rekrutmen pegawai secara terbuka, transparan, dan akuntabel. Namun, selain itu, Sekretariat Jenderal MPR-RI masih belum berhasil menyusun Analisis Jabatan maupun Evaluasi Jabatan, dan belum berhasil melakukan evaluasi kinerja pegawai. Juga belum berhasil melakukan pemetaan profil kompetensi individu pegawai berdasarkan hasil tes asesmen, serta belum berhasil menyusun Standar Kompetensi Pegawai dalam rangka penyelenggaraan Diklat Pegawai Berbasis Kompetensi. Sekretariat Jenderal MPR-RI juga belum berhasil mengembangkan sistem database pegawai yang mutakhir dan akurat, karena selama ini baru berhasil melakukan pembaruan data pegawai secara manual saja.

Idealnya, Sekretariat Jenderal MPR-RI mampu mengukur pencapaian program Penataan Sistem Manajemen SDM Aparatur ini dengan menggunakan 8 (delapan) indikator keberhasilan, meliputi (1) indikator perencanaan kebutuhan pegawai sesuai dengan kebutuhan organisasi, (2) indikator proses penerimaan pegawai secara transparan, obyektif, akuntabel, dan bebas KKN, (3) indikator pengembangan pegawai berbasis kompetensi, (4) indikator promosi jabatan secara terbuka, (5) indikator penetapan kinerja individu, (6) indikator penegakan aturan disiplin pegawai atau kode etik pegawai atau kode perilaku pegawai, (7) indikator pelaksanaan evaluasi jabatan, dan (8) indikator sistem informasi kepegawaian.

Keenam, Sekretariat Jenderal MPR-RI dalam pelaksanaan program Penguatan Pengawasan telah berhasil menerapkan Sistem Pengendalian Intern Pemerintah (SPIP) dalam rangka peningkatan ketaatan, efisiensi dan efektivitas pelaksanaan tugas dan fungsi para pegawai, sebagaimana tertuang pada Laporan Pelaksanaan SPIP Sekretariat Jenderal MPR-RI pada bulan Maret 2013. Selain itu, meskipun Sekretariat Jenderal MPR-RI telah berhasil membentuk unit kerja Bagian Pengawasan pada tahun 2013, namun masih belum berhasil meningkatkan peran Aparat Pengawas Intern Pemerintah (APIP) dalam rangka quality assurance dan konsultasi, guna meningkatkan kualitas pertanggungjawaban pengelolaan keuangan negara.

Ketujuh, Sekretariat Jenderal MPR-RI dalam pelaksanaan program Penguatan Akuntabilitas Kinerja telah menyusun Rencana Kerja Tahunan (RKT) Tahun 2013 yang terlihat pada Penetapan Kerja Awal Tahun 2013 dan tertuang dalam Laporan Akuntabilitas Kinerja Instansi Pemerintah (LAKIP) Akhir Tahun 2013. Juga telah menyusun Penetapan Kinerja Tahun 2014 yang tertuang dalam Rencana Kinerja Tahunan (RKT) Tahun 2014. Selain itu, Sekretariat Jenderal MPR-RI pada tahun 2014 juga telah berhasil menyusun Indikator Kinerja Utama (IKU), serta melakukan pengukuran pencapaian kinerja sesuai dengan IKU tersebut. 
Habsul, Analisis Pelaksanaan Reformasi Birokrasi Tingkat Mikro...

Kedelapan, Sekretariat Jenderal MPR-RI dalam pelaksanaan program Peningkatan Kualitas Pelayanan Publik selama tahun 2010-2014 masih belum berhasil menyusun dan menetapkan standar pelayanan publik, sehingga akibatnya para pegawai belum memahami standar pelayanan yang harus dilakukan dalam upaya meningkatkan kualitas pelayanan publik yang lebih cepat, lebih murah, lebih aman, dan lebih mudah dijangkau. Selain itu, Sekretariat Jenderal MPR-RI juga masih belum berhasil meningkatkan partisipasi masyarakat dalam penyelenggaraan pelayanan publik.

Kesembilan, Sekretariat Jenderal MPR-RI dalam pelaksanaan program Monitoring, Evaluasi, dan Pelaporan telah berhasil menyusun instrumen penilaian pelaksanaan reformasi birokrasi di lingkungan Sekretariat Jenderal MPR-RI, dan telah berhasil menyusun contoh format laporan pelaksanaan reformasi birokrasi, serta telah melakukan sosialisasi kegiatan monitoring reformasi birokrasi. Selain itu, Sekretariat Jenderal MPR-RI juga telah berhasil menyusun laporan evaluasi tahunan pelaksanaan reformasi birokrasi berdasarkan laporanlaporan monitoring pelaksanaan reformasi birokrasi yang telah terkumpul, dan telah dibahas dalam rapat evaluasi dengan Tim Kelompok Kerja yang terkait. Namun Sekretariat Jenderal MPR-RI masih belum berhasil menyusun pelaporan menyeluruh pelaksanaan reformasi birokrasi yang menurut jadwal seharusnya dilakukan pada semester kedua tahun 2014.

\section{Simpulan dan Saran (Conclusion and Suggestion}

Meskipun Sekretariat Jenderal MPR-RI telah melaksanakan langkah-langkah reformasi birokrasi, namun dalam pelaksanaannya masih belum sepenuhnya mengimplementasikan acuan-acuan reformasi birokrasi yang disarankan dari Kementerian Pendayagunaan Aparatur Negara dan Reformasi Birokrasi, terutama misalnya Sekretariat Jenderal MPR-RI masih kurang jeli dalam pemilihan dan penetapan quick wins program reformasi birokrasinya, sehingga antara lain mengakibatkan masih rendahnya perolehan nilai evaluasi reformasi birokrasi yang dilakukan oleh Kementerian Pendayagunaan Aparatur Negara dan Reformasi Birokrasi.

Sekretariat Jenderal MPR-RI dalam melaksanakan langkah-langkah reformasi birokrasinya secara umum terkesan masih timpang dan berjalan secara sektoral per unit kerja, dan belum terkoordinasi secara terpadu dalam pengelolaan dan pengendalian Tim Reformasi Birokrasi Sekretariat Jenderal MPR-RI, dimana ada unit kerja yang sudah melaksanaan amanat reformasi birokrasinya dengan tepat waktu, namun ada pula unit kerja yang masih terkesan melakukan amanat reformasi birokrasinya dengan setengah hati.

Selain itu, banyak dari pegawai Sekretariat Jenderal MPR-RI yang terkesan masih kurang "greget" (atau kurang bersemangat) dalam upaya melaksanakan langkah-langkah reformasi birokrasi di Sekretariat Jenderal MPR-RI. Juga terkesan masih belum terwujud adanya kesamaan persepsi dan pemahaman di antara para pegawai Sekretariat Jenderal MPR-RI tentang pentingnya pelaksanaan reformasi birokrasi di Sekretariat Jenderal MPR-RI. Atau, dengan kata lain, masih belum meratanya tingkat kepedulian para pegawai Sekretariat Jenderal MPR-RI terhadap kesuksesan program-program reformasi birokrasi di Sekretariat Jenderal MPR-RI.

Dalam rangka mewujudkan pelaksanaan reformasi birokrasi yang benar-benar berkualitas di lingkungan Sekretariat Jenderal MPR-RI, dalam arti mampu memperoleh nilai evaluasi pelaksanaan reformasi birokrasi yang relatif tinggi, yang pada giliran selanjutnya mampu pula memberikan tunjangan kinerja reformasi birokrasi yang relatif tinggi kepada para pegawainya, maka Sekretariat Jenderal MPR-RI hendaknya dapat melakukan langkah-langkah berikut ini.

Pertama, Sekretariat Jenderal MPR-RI melalui Tim Reformasi Birokrasinya, hendaknya dapat memilih dan menetapkan program quick wins reformasi birokrasi yang benar-benar menjadi potensi keunggulan secara kelembagaan dari Sekretariat Jenderal MPR-RI. Selanjutnya, manakala program quick wins reformasi birokrasi sudah 
disepakati dan ditetapkan, hendaknya segala daya dan upaya dapat dikonsentrasikan untuk mampu melaksanakan program quick wins reformasi birokrasi tersebut secara "all out" dan sepenuh hati. Untuk itu, maka adanya tingkat kepedulian yang cukup tinggi dari kalangan Pimpinan Sekretariat Jenderal MPRRI sangat diperlukan, guna memberikan arahan dan dorongan motivasi bagi segenap pegawai Sekretariat Jenderal MPR-RI, dalam mewujudkan suksesnya program quick wins reformasi birokrasi tersebut. Dengan terlaksananya program quick wins reformasi birokrasi secara berkualitas dan tepat waktu, diharapkan akan mampu menjadi momentum awal kesuksesan pelaksanaan programprogram reformasi birokrasi lainnya, sehingga perolehan nilai evaluasi pelaksanaan reformasi birokrasi di lingkungan Sekretariat Jenderal MPR-RI dapat cukup tinggi.

Kedua, tingkat kepedulian dan tingkat pemahaman seluruh pegawai Sekretariat Jenderal MPR-RI terhadap pelaksanaan reformasi birokrasi hendaknya dapat secara terus menerus selalu ditingkatkan, baik melalui kegiatan kursus ataupun diklat yang disertai dengan kegiatan simulasi, terutama dalam memahami beberapa panduan/pedoman pelaksanaan reformasi birokrasi yang telah diterbitkan oleh Kementerian Pendayagunaan Aparatur Negara dan Reformasi Birokrasi.

Ketiga, perlu dibuat standar operasional prosedur (SOP) tentang pedoman pelaksanaan reformasi birokrasi pada masing-masing program reformasi birokrasi terkait untuk dilaksanakan pada masing-masing unit kerja terkait pada Sekretariat Jenderal MPR-RI. Adanya standar operasional prosedur (SOP) pelaksanaan reformasi birokrasi tersebut dimaksudkan dan diharapkan dapat memberikan kepastian langkah reformasi birokrasi yang dilakukan oleh masing-masing unit kerja, sesuai dengan pedoman reformasi birokrasi yang ada.

\section{DAFTAR PUSTAKA}

Caiden, Gerald E. 1991. Administrative Reform Comes of Age. Berlin: Walter de Gruyer \& Co.
Denhardt, Janet V. \& Denhardt, Robert B. 2007. The New Public Service : Serving, Not Steering (expanded edition). Armonk. New York: M.E. Sharpe Inc.

Dwijowijoto, Riant Nugroho. 2004. Kebijakan Publik : Formulasi, Implementasi, dan Evaluasi. Jakarta: PT. Elex Media Komputindo.

Dwiyanto, Agus. 2015. Reformasi Birokrasi Konteksual : Kembali ke Jalur yang Benar. Cetakan Pertama. Jakarta: Kerjasama Lembaga Administrasi Negara (LAN) dan Gadjah Mada University Press.

Dwiyanto, Agus, dkk. 2012. Reformasi Birokrasi Publik di Indonesia. Cetakan Keempat. Yogyakarta: Gadjah Mada University Press.

Hermanto, Nailuredha. 2013. Reformasi Birokrasi dan Birokrasi di Era Reformasi. Padang: Universitas Negeri Padang.

Istianto, Bambang. 2013. Demokratisasi Birokrasi. Edisi 2. Jakarta: Kerjasama STIAMI Jakarta dengan Mitra Wacana Media.

Komarudin. 2014. Reformasi Birokrasi dan Pelayanan Publik. Cetakan Pertama. Bandung: Genesindo.

Mustafa, Delly. 2014. Birokrasi Pemerintahan. Cetakan Kedua, Edisi Revisi. Bandung: Alfabeta.

Nugroho, Riant. 2013. Change Management Untuk Birokrasi : Strategi Revitalisasi Birokrasi. Jakarta: Elex Media Komputindo.

Osborne, David \& Plastrik, Peter. 1997. Banishing Bureaucracy : the Five Strategies for Reinventing Government. California: Addison-Wesley Publishing Company, Inc.

Osborne, David \& Plastrik, Peter. 2004. Memangkas Birokrasi : Lima Strategi Menuju Pemerintahan Wirausaha 
Habsul, Analisis Pelaksanaan Reformasi Birokrasi Tingkat Mikro...

(terjemahan). Jakarta: Pustaka Binaman Pressindo.

Osborne, David \& Gaebler, Ted. 1996. Mewirausahakan Birokrasi : Mentransformasikan Semangat Wirausaha Ke Dalam Sektor Publik (terjemahan). Jakarta: Pustaka Binaman Pressindo.

Osborne, David \& Gaebler, Ted. 1992. Reinventing Government : How the Entrepreneurial Spirit is Transforming the Public Sector. New York: Penguin Book Ltd.

Pramusinto, Agus, dan Purwanto, Erwan Agus. 2009. Reformasi Birokrasi, Kepemimpinan dan Pelayanan Publik. Yogyakarta: Gava Media.

Sedarmayanti. 2013. Reformasi Administrasi Publik, Reformasi Birokrasi, dan Kepemimpinan Masa Depan : Mewujudkan Pelayanan Prima dan Kepemerintahan Yang Baik. Cetakan Ketiga. Bandung: Refika Aditama.

Shafritz, Jay M, Russel, E.W., and Borick, Christopher P. 2010. Introduction Public Administration. Pearson International Edition.

Shafritz, Jay M, and Hyde, Albert C. 1997. Classics of Public Administration. Cengage Learning US

Sinambela, Poltak Lijan. 2010. Reformasi Pelayanan Publik : Teori, Kebijakan, dan Implementasi. Jakarta: Bumi Aksara.

Thoha, Miftah. 2009. Birokrasi Pemerintahan Indonesia di Era Reformasi. Jakarta: Kencana Prenada Media Group.

Yin, Robert K. 2014. Studi Kasus : Desain dan Metode. Cetakan ke-13. Jakarta: Raja Grafindo Persada.

Artikel :

Hamidi, Muchlis, dan Khairi, Halilul. 2014. Reformasi Birokrasi : Menuju Peningkatan Pelayanan Publik, dalam Jurnal Ilmu Pemerintahan, Edisi Reformasi Birokrasi, Edisi 45 Tahun
2014, Jakarta: Masyarakat Ilmu Pemerintahan Indonesia.

Muskamal. 2014. Aktualitas Konsep Birokrasi Dalam Menjawab Tantangan Reformasi Birokrasi di Indonesia. PKP2A II. Makassar: Lembaga Administrasi Negara.

Dokumen :

Direktorat Evaluasi Kinerja Pembangunan Sektoral, Kementerian Perencanaan Pembangunan Nasional/Badan Perencanaan Pembangunan Nasional. 2013. Laporan Akhir Evaluasi Kebijakan Reformasi Birokrasi. Jakarta: Kementerian Perencanaan Pembangunan Nasional/Badan Perencanaan Pembangunan Nasional.

Jurnal Ilmu Pemerintahan. 2014, Edisi 45. Reformasi Birokrasi. Jakarta: Masyarakat Ilmu Pengetahuan Indonesia.

Peraturan Perundang-undangan :

Undang-Undang Dasar Negara Republik Indonesia Tahun 1945.

Ketetapan Majelis Permusyawaratan Rakyat Republik Indonesia Nomor 10 Tahun 1998 tentang Pokok-pokok Reformasi Birokrasi Pembangunan Dalam Rangka Penyelamatan dan Normalisasi Kehidupan Nasional.

Ketetapan Majelis Permusyawaratan Rakyat Republik Indonesia Nomor 11 Tahun 1998 tentang Penyelenggaraan Negara Yang Bersih dan Bebas Korupsi, Kolusi, dan Nepotisme.

Ketetapan Majelis Permusyawaratan Rakyat Republik Indonesa Nomor 7 Tahun 2001 tentang Visi Indonesia Masa Depan.

Undang-Undang Republik Indonesia Nomor 7 Tahun 2001 tentang Visi Indonesia Masa Depan.

Undang-Undang Republik Indonesia Nomor 25 Tahun 2004 tentang Sistem Perencanaan Pembangungan Nasional. 
Undang-Undang Republik Indonesia Nomor 17 Tahun 2007 tentang Rencana Pembangunan Jangka Panjang Nasional Tahun 2005-2025.

Undang-Undang Republik Indonesia Nomor 37 Tahun 2008 tentang Ombudsman Republik Indonesia.

Undang-Undang Republik Indonesia Nomor 25 Tahun 2009 tentang Pelayanan Publik.

Undang-Undang Republik Indonesia Nomor 5 Tahun 2014 tentang Aparatur Sipil Negara.

Undang-Undang Republik Indonesia Nomor 17 Tahun 2014 tentang Majelis Permusyawaratan Rakyat, Dewan Perwakilan Rakyat, Dewan Perwakilan Daerah, dan Dewan Perwakilan Rakyat Daerah.

Undang-Undang Republik Indonesia Nomor Nomor 30 Tahun 2014 tentang Administrasi Pemerintahan.

Undang-Undang Republik Indonesia Nomor 42 Tahun 2014 tentang Perubahan Atas Undang-Undang Nomor 17 Tahun 2014 tentang Majelis Permusyawaratan Rakyat, Dewan Perwakilan Rakyat, Dewan Perwakilan Daerah, dan Dewan Perwakilan Rakyat Daerah.

Peraturan Presiden Republik Indonesia Nomor 81 Tahun 2010 tentang Grand Design Reformasi Birokrasi 2010-2025.
Keputusan Presiden Republik Indonesia Nomor 49 Tahun 1999 tentang Organisasi Sekretariat Jenderal Majelis Permusyawaratan Rakyat Republik Indonesia.

Keputusan Presiden Republik Indonesia Nomor 23 Tahun 2010 tentang Perubahan atas Keputusan Presiden Republik Indonesia Nomor 14 Tahun 2010 tentang Pembentukan Komite Pengarah Reformasi Birokrasi Nasional dan Tim Reformasi Birokrasi Nasional.

Peraturan Menteri Pendayagunaan Aparatur Negara dan Reformasi Birokrasi Republik Indonesia Nomor 20 Tahun 2010 tentang Road Map Reformasi Birokrasi 2010-2014.

Peraturan Menteri Pendayagunaan Aparatur Negara dan Reformasi Birokrasi Republik Indonesia Nomor 14 Tahun 2014 tentang Pedoman Evaluasi Reformasi Birokrasi Instansi Pemerintah.

Elektronik :

Arisman. Tanpa Keterangan Tahun. Reformasi Birokrasi dan Reinventing Government : Upaya Peningkatan Kualitas Pelayanan Publik. Makalah selaku Fungsional Widyaiswara Kementerian Hukum dan Hak Asasi Manusia. Jakarta: http://www.academia.edu/8757109/Mak alah_Reformasi_Birokrasi 